\title{
Светлана Шеатовић
}

Институт за књижевност

и уметност, Београд

svetlana.seatovic@gmail.com

https://doi.org/10.18485/ai_diskurs_pobede.2019.ch3

821.163.41.09

930.85(292.46)

\section{ЛАТИНСКИ СВЕТ У АНДРИЋЕВИМ ПРИПОВЕТКАМА И ДУЧИЋЕВИМ ЕСЕЈИМА - ТИХИ ПОБЕДНИЦИ ${ }^{1}$}

У раду ћемо дефинисати порекло слике Латина од народне књижевности која се уграђује у Андрићеве приповетке у којима је Дубровник топоним и синоним града под утицајем Латина и Венеције до модерне свести антрополошког карактера о односу копна и мора. Упоредо са одабраним приповеткама Иве Андрића „Пут Алије Ђерзелеза“, „Два записа о босанском писару Дражеславу“ пратимо и идеје о латинском свету у есеју о Иву Војновићу Јована Дучића, али и путописима Милоша Црњанског. У анализама се ослањамо на сазнања геофилозофије (К. Реста) и анализама менталитета Јована Цвијића.

Кључне речи: геофилозофија, море, копно, Латини, култура, простор.

Дискурс победе у култури увек је део програма, јасног или прикривеног. Латински свет је улазио вео-

1 Рад је настао у оквиру рада на пројекту Смена йоейичких йараgиіми у срйској књижевностии 20. века: национални и евройски контеиексй (178016) који се одвија у Институту за књижевност и уметност, а финансиран је средствима Министарства просвете, науке и технолошког развоја Републике Србије. 
ма тихо у приобална подручја и Босну о чему сведоче Андрићеве приповетке, Дучићева поезија и есеји, путописи Милоша Црњанског, али у уметничком облику ослањајући се на историјске чињенице. Геофилозофија (Катарина Реста, Масимо Качари) као новија дисциплина нам отвара могућности за тумачење и разумевање позиције победника и дискурса културног поробљавања на рубним просторима Медитерана, а у нашим ареалима то је приобално подручје Јадранског мора. Тихи победници у Дубровнику су Млечани у културолошком смислу, али Иво Андрић ту доминацију кроз приповетке доживљава као „онај други свет преко мора“. То је облик двојства личности и културе која је уграђена у филозофију Дубровчана насупрот људима залеђа. Дискурс победника који долази кроз доминацију католичке вере и културних образаца на простору Дубровника и у свести јунака Дубровчана кроз Андрићеве приповетке су феномени победе и победника. Тако су често Дубровчани описани као слободни јунаци у које је уграђен модел Венеције као политичког и културног победника. Насупрот те „тихе победе“ стоје јунаци који долазе у Дубровник из залеђа и виде ту победничку доминацију уграђену у моделе слободног града и републике, а најупечатљивији примери се виде у приповеткама „Два записа писара Дражеслава“ и „Дубровачка вејавица“. Ипак, Андрићева слика латинског света је шира и комплекснија, а видљива и у другим прозним делима.

Латински свет је вишеструко присутан у Андрићевом опусу, од приповедака преко романа, пре свега Травничке хронике, На Дрини ћуйрије и можда још најмање Проклетие авлије. Поред те слике латинског света који се појављује на просторима Босне, од фрањеваца преко конзула, трговаца и јунака који стижу преко мора, а најчешће су Млечани, Андрић у приповеткама гради много сложенију слику тог латинског света виђеног очима домицилног становништва, као у слу- 
чају Селима Циганина који никако не може да разуме скромност и уметничку посвећеност архитекте безименог неимара у приповеци „Мост на Жепи“. То су сусрети две цивилизације у којој је представник те друге латинске цивилизације у служби Отоманске империје саградио мост на Жепи који ће бити прототип моста на Дрини. Између Селима Циганина и ћутљивог, преданог и замишљеног неимара је културолошки зјап, неразумевање две цивилизације, два нивоа образовања, али и облик тихе поробљености у којој је уметничко дело укротило сурову и дивљу Жепу. Тако се у неким од приповедака као што је „Мост на Жепи“ појављују јунаци из латинског света као уметници, лучоноше и тихи окупатори и победници тамне и мрачне Босне.

У триптих приповеци „Пут Алије Ђерзелеза“, најранијој приповеци Иве Андрића, над несрећним и карикатуралним ликом Алије Ђерзелеза ${ }^{2}$ вишеструко доминира лепа Венецијанка која га поробљава господством, лепотом, грациозним ходом. Лепота безимене Венецијанке која је била део дипломатске мисије и на путу за Цариград занела је и сасвим „поробила“ Алију Ђерзелеза испред кога иде слава, како каже приповедач иронизујућу његову позицију несрећног и неуспешног љубавника. Трчећи за Венецијанком у Вишеграду кроз хан Алија ће остати само занет и очајан када му та лепа жена залупи врата и иза ње остане само бели и зелени вео. То је сенка победничког света, деликатног, прорачунатог, одмереног у коме је Алија Ђерзелез заробљеник емоција и сигурни губитник. Слична ситуација биће и у сцени са Катинком, воћем које зри у хладу, девојком полатињеном са свим особинама које

2 Видети наш рад о верском и националном идентитету жена у приповеци „Пута Алије Ђерзелеза“: Светлана Шеатовић, „Жене Алије Ђерзелеза“, Свеске Заяужбине Иве Анgрића, св. 30, Београд, 2013, стр. 187-208. 
одражавају тај свет цивилизацијских победника. Алија Ђерзелез је свакако иронија несрећног љубавника који неће доспети ни до Циганке Земке и само прав пут ће водити до „куповне“ жене Јекатерине. Лик лепе и тајновите Венецијанке је један од првих латинских ликова у Андрићевим приповеткама који ће донети типичне особине „Латина, старих варалица“ и тешко достижних жена преко мора из наше народне поезије. Те жене преко мора биће доступне само цару Душану и Максиму Црнојевићу, али то је сталешки успех из народне књижевности у којој је то типизиран облик победника, а уговорене свадбе су успевале само владарима јер је то био део јасног политичког плана. Несрећни Алија не може допрети до Венецијанке већ ће остати запаљен ударцем врата и звуком кључа у брави.

Други значајно сложенији модел „тихих победника“ у Андрићевим приповеткама налазимо у низу приповедака везаних за Дубровник и његову околину. То је комплекснија слика у којој су победници ушли на „мала“ врата кроз културу и веру баш као што су то само много дубље и трајније урадили Византинци са документом De administrando imperio у 9. веку када су своје северне границе и Словене са којима су водили дуготрајне борбе одлучили да поробе не оружјем већ вером, језиком и културом. Ми смо остали баштиници те мудре византијске политике док је ова друга млетачка, латинска, налазила мање систематичне, али опет врло успешне, путове покатоличавања, увођења мисија фрањевачког реда и интензивних културних веза које су обогатиле, али латинизирале кулутру у обалном појасу Дубровника и Боке Которске. Андрић ${ }^{3}$ као изузетан познавалац исто-

3 Видети: Светлана Шеатовић, „Брђанска туга и умереност приморја-Андрићев Јадран“, Иво Андрић у нашем времену, ур. А. Вранеш, Андрићев институт, Андрићград-Вишеград, 2018, 43-64. 
рије на простору Босне, па и приморја, сасвим јасно уводи ликове јунака и слике латинског сета у приповеткама „Два записа босанског писара Дражеслава“, „Дубровачка вејавица“, „Сусрет“ и другима.

Тај комплексан сусрет латинског и православног света, две цивилизације на простору Дубровника и залеђа у исто време дубоко ће интригирати и Јована Дучића и то у путописима везаним за Јонско море, а његове најраније „Дубровачке поеме“ и „Јадрански сонети“ настали пре Првог светског рата биће период латинизираног Дучићевог погледа на тај обални појас. Занимљиво је да ће оба писца најдубље анализирати ту слику између два рата, а Андрић ${ }^{4}$ чак у последњој стваралачкој фази крајем педесетих и почетком шездесетих година. Победничка слика латинског света на простору Дубровника биће сасвим јасна Дучићу у есеју „Иво Војновић“ тридесетих година и, мада нема прецизних сазнања да је Дучић био у било каквој вези са настанком даљих Андрићевих приповедака, сасвим је јасно да можемо видети неку врсту генезе сазнања и резимирања у којима и један и други писац постају свесни латинизације Дубровника и региона око Републике, а тиме и двојства у јунацима који долазе из Херцеговине у Дубровник. Јаз између једних и других остаје непремостив. Андрић је ту врсту двојства геофилозофије која је уткала у себе све сударе рубних подручја копна и мора, а у овом случају православне вере и католичке вере и западне цивилизације у јунацима целог циклуса приповедака о Дубровнику.

Победници нису чак ни физички присутни као што ће то бити видљиво у ликовима муслиманског света и представницима османске власти. Латински свет ће

4 Андрић се посветио теми Дубровника у низу приповедака: „Два записа босанског писара Дражеслава“, „Дубровачка вејавица“, али и у деловима Знакова йореg йyйа у којима анализира Боку Которску са становишта менталитета и утицаја латинске културе. 
имати само своје изасланике, невидљиве и тајне руке које су придобијале људе, преводиле у католички свет, придобијале их за културу и уметност Венеције, подстицали копирање Дубровачке републике по моделу Млетачке републике и, иако је тај град република био слободан, он је суштински био верски и културно окупиран. Латински свет је успео да тихом и ненасилном окупацијом придобије становнике Дубровника иако су њихова порекла била српска, православна и, мада су њихови преци сишли са брда и планина из залеђа, та врста порекла се полако брисала.

Ипак, латински свет као тихи победник који никада није окупирао дословно Дубровник већ је постао конститутивни део културолошке слике, па и његово залеђе појављују се у низу Андрићевих приповедака везаних за тај простор. У овом сегменту већ се можемо ослонити и на нову област геофилозофије која у последњим деценијама даје нову слику Европе, али и Медитерана који су одређени географским особинама, али и филозофијом света који живи на мору ослањајући се на копно. У тим увалама и затонима се преламају односи копна и мора, а у приповеткама везаним за Дубровник и околину то су и верски сусрети латинског и православног света. На тим уским линијама где је и протеривање из Дубровника у Стон значило егзил у српску православну епархију истовремено нам дозива проблем полатињеног Дубровника, његових становника чије порекло је често било српско и православно. Прилагођавањем латинском свету Венеција никада неће поробити дословно Дубровник, али ће овај град бити њена реплика у којој ће његови становници покушавати да унесу све слике и одлике Млетачке републике. Тиха окупација и победничка доминација која није развијена у дословну територијалну доминацију 
представља свет у коме је култура и вера покорила једну слободну републику за коју су често Млечани волели да кажу да је само општина. До сада је у науци било неколико врсних тумачења ${ }^{5}$ ових приповедака, романа и записа Знакови $\bar{u}$ ореg $\bar{u} y \bar{u} a$ у бројним текстовима у последњих двадесетак година.

У филозофији и науци о књижевности у последњих десет година развија се и термин „геофилозофија“ који анализира кроз неколико дисциплина однос човека и простора у коме живи. Посебно значајно дело је филозофска и културолошка расправа Катерине Реста Геофилозофија Меgитиерана (2012) која тумачи симболику односа човека копна и судара са морем која обележава све границе Медитерана, а јадранске обале су посебно типичне по бројним увалама и дубоким контактима две целине. У савременом свету где се мењају позиције Медитерана као једног затвореног мора и Атлантика као глобалног света Јадранско море се са тачке гледишта човека Балкана може видети као једно велико језеро, али преко тог језера се пружа погледа са Дучићевог Леотара до Италије. То језеро или Јадранско море није лишено бројних одлика медитеранских карактеристика управо у сусретима копна и мора. Дучићев поглед стиже из залеђа мора, са последњих делова Балканског масива и отвара видокруг ка другој обали коју обележава и друга култура, цивилизација и географске особине. Сусрет људи из

5 Никша Стипчевић „Андрићево читање извештаја млетачких амбасадора“, Свеске Заяужбине Иве Анgрића, 1985, 3, стр. 111-169; Ерос Секви, „Андрић, Италија и Италијани“ у зборнику Иво Анgpuћ, Институт за књижевност и уметност, 1962, Злата Бојовић „Занимање Иве Андрића за дубровачке теме“, предговор у Иво Анgрић и Дубровник, Андрићев институт, Андрићград, 2017, 7-26; Бојан Ђорђевић „Наративност предела: Андрићеви медитерански записи“, Acqa alta Mеguӣерански иеејзажи у моgерној срйској и ийалијанској књижевносиии, ИКУМ, 2013, 507-517. 
залеђа са утицајима мора које превазилази географску одредницу и постаје културолошки симбол отвара нам простор за нова разумевања и анализе и Дучићеве позиције у нашој књижевности, његове слике света у коме није могуће избећи термин „завичај“ и људе који су са тог простора поникли. Судар залеђа и мора је далеко више од географског и културолошког сусрета и савремена геофилозофија је дала потврду за ту врсту истраживања. Географија, култура, идентитет, језик, наслеђе, завичај и симбологија артефаката античког корпуса уметности са посебним уделом дубровачког региона представља сложену слику која се пружа кроз Дучићеву поезију, а потом и преко путописа, све до шпанске Авиле. Јован Дучић је наш први писац који покушава да сазна како и којим путевима стиже наша фасцинација морем, латинском културом којој је и он био усмерен у младости у „Јадранским сонетима“ да би прешао тај пут и стигао до есеја посвећеном Иву Војновићу 1929. године када већ јасније види однос та два света који се сударају на ивицама и ободима копна и мора. Ти сусрети ће бити везани за облике „тихог поробљавања“ или латинизације једне културе која је била утемељена на византијском наслеђу и народном стваралаштву. Однос копна и мора је дуж целог Медитерана однос поробљених и великих владара и о томе веома јасно пише Катерина Реста представљајући то као општији сусрет и симбологију мора и залеђа:

Медитеран је пак сећање на једну другачију прошлост; у светским размерама, јединствено искуство сусрета између копна и мора, простор поделе који одваја и раздваја, али такође и повезује и обједињује, поспешујући преплитање идентитета који, у непрестаном суочавању, желе да остану различити. У том плуралитету граница и територија, представљао је простор сукоба, али такође и изванредних сусретања, простор неисцрпног поређења са другим, спречавајући и ублажавајући свако драстично 
свођење на исто, reductio ad unum. Из тог мора разлика рођена је Европа, несводљиви йлуриверзум народа и језика, подстакнутих да воде дијалог, нагнаних на непрекидни напор превођења и удаљавања. (Реста 2017: 36-37)

Овај цитат као да нам отвара сву сложеност Европе, њених медитеранских граница, мешавину култура на ободима који се мешају са континенталним светом и истовремено постају део и Дучићевог видокруга који са Леотара по сунчаном дану досеже до обала Италије. За разлику од Андрића који ће у приповеткама „Дубровачка вејавица“ и „Два записа босанског писара Дражеслава“ показати још оштрије сударе босанског света са дубровачким госпарима Дучић једноставно као да великим делом свог духовног и културолошког бића већ припада том медитеранском или јадранском свету. Напокон, само 20 километара од обала Дубровника је довољно да се са ветровима са мора у Требињу стопе бројне особине света на мору и овог света који живи у његовој непосредној близини. Јадранско море је, као и цео Медитеран, море које спаја и раздваја ${ }^{6}$ као што на широј мапи медитеранског света мешају народи и културе.

Позитивно конотирана свест о другој, вишој цивилизацији која је везана за море развија се у српској књижевности код Иве Андрића, Милоша Црњанског, али и Растка Петровића и Милана Дединца, Јеле Спиридоновић Савић у периоду који почиње после Првог светског рата. Уједињењем Јужних Словена и стварањем Краље-

6 Медитеран су бројни савремени филозофи и историчари сагледали управо као море које спаја и раздваја или море усред копна над којим копно доминира, али су народи због свог географског положаја усмерени једни на друге. Дијалог две обале је општа слика коју веома јасно дефинише Ф. Хоркани у делу: HORHANI, F,Tradizione e modernitá: le condizioni del dialogoo fra le due sponde" u: Mediterraneo.Un dialogo fra le due sponde, ur. F. Horchani-D.Zolo, Roma:Jouvence, 2005. 
вине Југославије 1918. године многи писци, а посебно Црњански и Андрић, делове свог опуса усмеравају ка Јадранском мору укључујући обе стране, далматинску и италијанску. У таквим друштвеним и политичким околностима које су приближиле писце после Првог светског рата Јадранском мору треба имати у виду и чињеницу коју прецизно наводи Јован Цвијић у Психичким особинама Јужних Словена наводећи као изворни географ чињеницу да су Далмација и њено залеђе једна целина:

Далмација је у ствари само приморски део динарског залеђа. Она се не може потпуно развити, ако не чини једну државу са овим залеђем [....] Најмногобројније и најактивније далматинско становништво чине досељеници из унутрашњости. (Цвијић 2006: 140-141)

Не треба заборавити да све што је уз море или преко мора у српској народној књижевности носи печат окупације и непријатељског става према Млетачкој републици. Тај негативно конотиран став према Латинима као старим варалицама српска књижевност носи вековима кроз усмено, народно стваралаштво и један свесловенски став према окупатору. С друге стране, парадоксално, у народној књижевности наши највећи јунаци епских песама и балада - цар Душан, Максим Црнојевић, Милић Барјактар жениће се девојкама Латинкама преко мора или девојкама које живе поред мора, мислећи при томе и на другу, млетачку страну Јадрана. Та традиција се наставила у 19. веку у романтизму и реализму. Најдубљи пример културолошког неразумевања према другој страни Јадрана, Венецији и Трсту, показаће Петар Петровић Његош ${ }^{7}$ средином 19. века у Горском вијенцу у монологу Војводе Драшка у

7 Видети наш рад: Светлана Шеатовић Димитријевић, „Његошева слика Италије и Латина“, Научни састанак слависта у Вукове дане, МСЦ, Београд, 2014, бр. 43/2, стр. 471-481. 
Млецима. Међутим, Његош ће показати сасвим другачије и шире погледе на Трст, Венецију и Напуљ у путописним документима. Наша прва путописна трагања ка тој другој, морској и медитеранској цивилизацији почињу путописима Љубомира Ненадовића Писма из Ийалије. Тек почетком 20. века песници полако мењају ту перцепцију, па тако роматичарски песник Лаза Костић у последњој заветној песми „Santa Maria della Salute“ афирмише лепоту ове цркве у Венецији исказујући покајање за све прекоре које је и сам написао поводом сече далматинских шума у песми „Јадрански Прометеј“. Јован Дучић као песник симболизма се почетком 20. века позитивно односи према наслеђу Дубровника и као песник рођен само 20 километара у залеђу мора уноси позитивније ставове према мору. Дакле, тек после Првог светског рата мења се перцепција мора, а посебно Јадрана и његових острва процесом уједињења Јужних Словена у једну државу Краљевину Срба, Хрвата, Словенаца, а потом у Краљевину Југославију. Иво Андрић ће и сам рећи да му је једном приликом Дучић рекао да се одмакне од тих брда и да се спусти на море, па ће и сам казати да је Дучић пролио море испред његових очију. Милош Црњански објављује збирку Лирика Ийаке 1919. у којој се појављује Јадранско море као једно од мора, али су његове опсесије у складу са експресионистичком поетиком упућени ка Суматри и далеким коралним морима. Ипак, неколико песама је посвећено управо „Јадрану“, „Сан Вито“ и „Моја песма“ у којој ће двојна душа песника бити смештена у ,једној гондоли у Венецији у време карневала“. Црњански ће посебно изван ове збирке објавити и песму „Лето у Дубровнику 1927.“ $у$ у којој ће његова ду-

8 О теми Јадрана и мора код Црњанског смо опширно писали у раду: Светлана Шеатовић Димитријевић, „Итака и коментари - између панонског и медитеранског мора“, Кулйуре у gujaлої, Књижевност и мултикултуралност, књ. 2, међународни зборник радова, уредили Александра Вранеш, Љиљана Марковић, Филолошки факултет, Београд, 2013, стр. 61-79. 
ховна трагања пронаћи мир тек ту испод Срђа и у залеђу наших гора и мора. Култура памћења, како ће је у савременом добу представити Алаида Асман указаће нам на оно чега је био свестан Милош Црњански и његова генерација песника. Јадран је био у овој песми за Црњанског одраз колективног „ми“ баш као што Асманова каже: „Свако 'ја' повезано је са једним 'ми' које му обезбеђује важне основе његовог сопственог идентитета... Различите ми-групе с којима се појединац повезује одсликавају спектар хетерогених, мање или више узајамно искључивих чланстава“" (Асман 2011: 19).

Јован Дучић тек у путописима који настају у зрелом животном добу ретроспективно обнавља искуство мора, одрастање уз дубровачке обале и повратак у унутрашњост касно ноћу. У „Писмима са Јонског мора“ Дучић прецизно описује флору и фауну дубровачких затона, па су ту мириси борића и смрека, ваздух има мирис рузмарина и јасмина, а изнад лете јата ласта. За Дучића је море само оно дубровачко море јер спознаја мора је могућа само ако се то догађа у детињству. Копно је апатично, студено и тихо и такве брегове и поља ће Андрић у приповеткама назвати „брђанском тугом“ која обавија људе који долазе из унутрашњости у Дубровник. У низу приповедака о босанском писару Дражеславу Андрић је истакао управо ово што и Дучић назива „грубом и студеном тишином“, „апатичном лепотом“ која га одбија док је његовој „души пуној роморења“ пријатније уз море и на светлости Сунца које се одражава на пучини. Овим малим описима и ретроспекцијама доживљаја најранијег детињства утканим у путопис по Јонском мору Дучић пледира за „јужњачку мисао“ и филозофију предсократоваца који ће у светлости видети истину и лепоту. За Јована Дучића свет светлости и сунчане стране насупрот хиперборејским маглама је онај простор који је осећао и 
разумевао геофилозофски као свет бољих могућности. Лично искуство у детињству је пресудно за разумевање мора коме је Дучић очито припадао сензибилитетом и местом рођења.

Низ Андрићевих приповедака и записа тематизује културолошку перцепцију Јадрана и латинског света из позиције човека копна (Босне). У ту групу приповедака улазе следећа дела: „Предвечерњи час“ (1961), „Два записа босанског писара Дражеслава“ (1963), „Тренутак у Топлој“ (1963), „Сусрет“ (1969), „Дубровачка вејавица“ (1968/1969), „Занос и страдање Томе Галуса“ (1931), „Робиња“ (1976). Највећи део тих приповедака настао је после Другог светског рата и представља јасну развојну линију која почиње биографским искуством писца затвореног у сплитску тамницу 1914. године преко ратног боравка на Јадрану, нове антрополошке и културолошке свести о два света; копна и мора. У есејима „Летећи над морем“ (1932), „Сан о граду“ (1923) и приповеци „Занос и страдање Томе Галуса“ (1931) између два рата Андрић износи прве идеје које ће бити метафизички и онтолошки оквир за његове јунаке у приповеткама насталим после Другог светског рата.

Највећу пажњу привлачи есеј „Сан о граду“ који је објављен 1923. године. То је апотеоза „господству и слободи као најдостојнијим људским сновима“ у граду некадашњој републици, али и свест о судару босанског и херцеговачког крша са морем. По први пут Андрић у свом опусу указује на ове сударе у географском и културлошком виду: „Замислите да се раздеран, стрм и оштар босански пејзаж и херцеговачки крш тање и профињују на свом путу према мору, док се не сложе у масивну али фину и озбиљну линију - то је Срђ“"(Андрић 2011: 125). После јасне географске линије Андрић одмах прелази на језик као базичну тему идентитета: 
„Замислите наш говор како се из Босне, преко Херцеговине, глади и мекша, доке не стигне у Жупу дубровачку, где га сељакиње говоре с лепотом и достојанством краљица“" (Андрић 2011: 125). У том сну о граду Андрић као и Црњански у путописима по острвима, а посебно у путопису о Сплиту насталом у истом периоду указује на исту цивилизацијску линију, како чобани са планина бацају своје мешине и уче се да „тргују и стичу“. Црњански ће и у путопису есеју о Дубровнику изнети веома сличан став као Андрић:

[...] и врати се да се смирим, наслонивши плећа опет на брда своје земље, и одморим се од све те промене и празнине света, од све те помаме за туђином, под својим Срђом. Тада нисам ни слутио да ћу на нашој обали наћи град који ће ме дубином неба и тишином живота, лепотом биља и ноћних сазвежђа својих, примирити. (Црњански 1995: 203)

Овако је писао Црњански у путопису „Дубровник“ 1927. године. Андрић ће као и Црњански пронаћи сударе географије, али и господство којим се на нашим просторима могу умекшати гласови наших „Словина“. Тек „Примивши веру и цивилизацију тога времена они - граде“ (Андрић 2011: 125). Дубровник за Андрића постаје метафора Града именованог великим словом јер то је град у коме се оштре линије вајају, а глуви крш и безумно море стварају своје место у коме приповедач види најлепши допринос човека у изградњи, али и месту где су игра, плес и уметност имали погодно тло за развој људске мисли. Андрић у апотеози Дубровнику, синониму града који је радом, мудрошћу и законима постигао славу и богатство, указује на феноменологију градње коју ће развијати у целокупном делу (приповеци „Мост на Жепи“, роману На Дрини ћуйрија) сугеришући нам да све што има неки 
смисао остаје иза нас у оквирима архитектуре и уметничких дела. Клањајући се „вјери, господству и слободи“ док чита Ива Војновића Андрић поставља обрисе тог света ка коме ће се спуштати његови јунаци из крша и планина. У есеју „Летећи над морем“ из 1932. године Андрић повлачи јасну линију судара човека балканских планина са морем као експлозијом. Идеја о изласку једног племена на море je „[...] почетак његове праве историје и улазак у царство већих изгледа и бољих могућности“. Дакле, опет у контексту Црњанског и његових есеја о Сплиту и Дубровнику налазимо јасну и књижевноисторијску корелацију идеја два млада писца богатог предратног искуства. Међутим, Андрић ће тај излазак на море једног племена јасније развити тек у приповеткама после Другог светског рата. Црњански ће остати на својим позицијама и ту везу са морем ће само описати као облик сећања и промишљања у Ийаци и коменииарима 1958. године.

Андрић феноменологију преласка са копна на море види као „важан пут одуховљења“ јер се изласком на пучину „путује ка савршенству“. У овом фантазмагоријском есеју Андрић трансформише чак и планинско биље у нежну флору медитеранског поднебља: „Оморика постаје кипарисом, планинска дивљака слатком смоквом, а безимена трава рузмарином“ (Андрић 2011: 12). Горчина морске воде је здрава јер је лек и опет пут ка савршенству. После флоре и географије Андрић прелази на унутрашња духовна стања која се лече уз море. Као и Црњански који ће казати у „Нашим небесима“ да у Дубровнику су небеса „Без и једне појаве туге“ тако ће Андрић указати на антрополошку особину човека копна називајући га „брђанском тугом“ коју ће излечити море:

Поверите вашу брђанску тугу мору; оно је бескрајно и неодољиво као непрестан позив на даље путовање. Ту 
на каменој ивици, на поглед мора, умукла је наша брђанска песма и завршила ускликом задивљеног изненађења. Постајемо лаки и вешти. Бродимо. (Андрић 2011: 13)

Овим идејама о тузи која се лечи уз море или местима где нестаје „брђанска туга“Андрић и Црњански потврђују Цвијићеву тезу о „одсуству фаталистичке резигнације којом је захваћено становништво Балканског полуострва“ (Цвијић 2006: 142). „Летећи над морем“ је фантазмагоријски, али дубоко етнопсихолошки, есеј који синтетише менталитет динарског човека са светом Приморја у коме се баш кроз језик, говор и песму препуну туге трансформише људско биће у духовни свет радости, лакоће, трајања: „Талас постаје крило. Бивамо бестелесни и срећни. Летимо“.

Другу и много сложенију слику самосвести о односу родног Требиња и Дубровника на међи Јован Дучић дефинише у есеју „Иво Војновић“.

У есеју посвећеном Иву Војновићу Дучић је на простору Дубровника сагледао однос копна и мора као суштинску особину овог града-републике по много чему сличном Венецији. Дучић закључује да се Дубровник бранио од копна, тиме и од српског утицаја кулама, а да је био и архитектонски и одбрамбено отворенији према мору:

Дубровник се већ од почетка утврђивао против континента већма него против мора. Дубровник се, нарочито са првим порастом силе немањићке државе, опасивао дебелим зидовима, да би се одвојио од српских династа, истина, не као етничка него као државна јединица. Она велелепна тврђава Минчета, која изгледа да стражари над целим морем и свима обалама Јадрана, подигнута је против краља Милутина. - И Венеција је тако себе изградила насред пучине да би остала неприступачна, и то пре свега неприступачна својим сународницима на копну. У 
таквој њиховој усамљености, која би изгледала оличење егоизма, ксенофобије, и скоро мизантропије, ове две јадранске републике су проживеле више него хиљадугодишњи државни живот, са подједнаком мудрошћу, ако не и са подједнаком славом. Оне су у себи нашле довољно силе за отпор и одржање, и довољно генија да свака од њих створи сопствено културно дело, и свој тип човека, и своје посебне дијалекте народног језика. (Дучић 2001: 15)

Однос копна и мора нигде није интензивнији и комплекснији и на географском, културолошком, етничком, државном и верском пољу као на простору Дубровника и његовог залеђа на путу до Требиња. На том простору се преламају најсложеније историјске прилике, државне а потом и верске, између православног и католичког света. Јован Дучић је веома добро разумео како копно задире у море и како Јадранско море улази у копнене затоне доносећи другу, високу културу ренесансе и барока и Италије, али и изразит католички напор да се Дубровник огради од православног залеђа. Међутим, географске, хидролошке и културолошке прилике су неумитно упућивале Дубровник на залеђе и Херцеговину, а потом кршне људе камените Херцеговине да се упуте ка граду и његовом свету обележеном другом цивилизацијом. Дучић истиче у тексту о Иву Војновићу историјски контекст односа Дубровника и средњовековног залеђа:

Горе иза Срђа и изнад Бргата, било је наше сјајно српско царство и господство. Онамо су били и двори легендарних дванаест краљева Мавра Орбина, о којима се већ од почетка 18. века у Дубровнику учило; а горе у Требињу код Требишњице, као у Брзјаку у Расу, били су двори краљице Јелене Анжујске. У Бранковини код исте Требишњице се и сад показује феуд династије Бранковића, која се најпре овде и спомиње. Дубровник је из тог краја одозгор примао и воду Требишњице, која као понорница 
Омбла излази у близини града светог Влаха. Све крвне и духовне исхране долазиле су овом граду одозгор већ спочетка.... Између Дубровника и народа у његовој позадини била је разлика углавном државничка и политичка, а тек касније верска и културна. (Дучић 2001: 19-20)

Дубровник је изузетно занимљив за Дучића јер ће и у „Писму са Јонског мора“ описивати детињство у коме је спознао море, увале и затоне дубровачких обала. То није било спознање географског већ управо онога што данас називамо геофилозофским погледом на један простор и његове више, метафизичке одреднице. Ипак, Дучић је по питању Дубровника вишеструко дефинисао свој однос према том медитеранском драгуљу који је био дубоко географски и историјски везан за залеђе са јасно усмереним погледом на Венецију. Двојство Дубровника који се изградио на наслеђу залеђа, његових етничких припадника, водама и бреговима усмерено је ка Венецији у културолошком и верском аспекту као извору „тихог поробљавања“. Тако је и Дучић јасно видео двојство овог града, који ће неколико деценија касније увидети и приповедачки прецизно описати Иво Андрић у приповеци „Дубровачка вејавица“, „Два записа босанског писара Дражеслава“. Писар Дражеслав ће у анализи Дубровчана закључити да је реч о једној посебној групацији људи која је одређена двојством елемената воде и копна: „Променљивост је начело овог живота на два елемента, на земљи и води. И док те твој дубровачки преговарач убеђује у нешто, никад не знаш да ли говори с копна или с мора“ (Андрић 2011: 98-99). Предели у залеђу Јадранског мора су одређени дуализмом различитих географских одредница копно-море који су увек условљавали и антрополошке различитости, а још чешће и верске и националне поделе које нас воде ка дускурсу победника. 
Етничко порекло и близина херцеговачког залеђа обележеног српском средњовековном историјом, митовима и легендама уграђују се у ту сасвим специфичну групацију људи коју је и Јован Цвијић назвао „јадранским варијететом“. На тим танким нитима херцеговачког крша и Јадранског мора у оквиру дубровачких бедема одвијала се вековима једна сасвим специфична култура прожета мешавином латинског света и наслеђем српске народне књижевности стварајући свет модерног трговачког и поморског центра са јаким везама у целом Средоземљу. Дучић пишући о Иву Војновићу подсећа да је Гундулић певао о Косову и српским јунацима, док је Дубровник доводио у везу са смедеревским деспотима и њиховим потомством. У наставку овог става везаног за залеђе и српску историју Дучић каже:

Али ту сродност Дубровник није нарочито ни порицао. Дубровник је био до краја више под утицајем талијанским, културно, него под утицајем српским, језично, и то само на своју штету. Својим одвојеним грађанским друштвом постао је Дубровник различнији од околног света народног типа. Али само друштво, и то највећма, које је иначе било врло искључиво, али никад несрпско, а нарочито антисрпско. (Дучић 2001: 21)

Тако је латински свет ушао у просторе и Дубровника који јасно описује Јован Дучић у есеју „Иво Војновић“ где је то посебна целина којој је тежио у поезији отварајући тако своју самосвест као медитеранску и он постаје један од веома важних текстова за концепцију његовог медитеранизма. Двојство Дубровника, града на копну и мору је истоветно Венецији, која представља то двојство својствено целом Медитерану. Због тога је Дубровник опасујући се кулама према копну постао једна јасна дефиниција у Дучићевом есеју о Иву Војно- 
вићу: „Дубровник је увек био град а не раса; йолис, а не іенос. Дубровчанин никад није дозвољавао да га зову Далматинцем, а камоли Херцеговцем“ (Дучић 2001: 23). Латински свет је тихом окупацијом кроз културу и веру успео да освоји Дубровник и потисне наслеђе српске народне књижевности. Продор тог латинског света био је видљив и у залеђу, али са јаким отпором кроз веру и културно наслеђе.

Иво Андрић је то двојство човека копна и мора видео јасно у приповеткама објављеним пред крај живота или чак постхумно објављеним из рукописа. До сада смо већ писали опширније о тим приповеткама, али за ову прилику указујемо само на слику латинског света која се формира у једно језгро тихог поробљавања културом. Језгро свих ових типова приповедака везаних за Јадранско море проистиче из есеја „Летећи над морем“ и „Сан о граду“. Историјску основу је потврдила Злата Бојовић у лику писара Дражеслава Бојића чији прототип је историјска личност из 14. века, писар бана Твртка кога је преузео од стрица бана Стјепана Херцега. Писар Дражеслав је јунак који повезује низ приповедака објављених од 1961. године („Предвечерњи час“, „Два записа писара Дражеслава“, „Дубровачка вејавица“, „Сусрет“). Двојство у јунаку Дражеславу је двојство човека који носи менталитет динарског типа личности жељан да се приклони атмосфери и навикама дубровачког миљеа, климе и друштвених навика. Насупрот уморног и незадовољног писара Дражеслава, онога који носи „брђанску тугу“, стоји лекар Италијан, весео, румен, умерен као представник Медитерана. Слика писара Дражеслава Бојића је пример јунака са историјском основом који је успео да се некако уклопи бар привремено у латински Дубровник, али никада до краја. Двојство овог јунака је антрополошка слика лич- 
ности која је остала на међи, а под снажним утицајем латинског света. На крају сам јунак ће остати негде између својих брда и благих медитеранских, али и латинских облика културе и стила живота.

\section{Извори и литература}

Андрић, Иво. Приче о мору. Београд: Лагуна, 2011. Штампано. Асман, Алаида. Дуїа сенка йрошлосӣи: кулиичра сећань и йо-

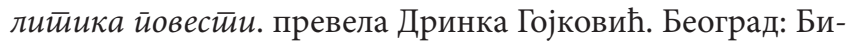
блиотека XX век. Књижара Круг, 2011. Штампано.

Бојовић, Злата. „Занимање Иве Андрића за дубровачке теме“. Злата Бојовић (ур.). Иво Анgрић и Дубровник. Андрићград: Андрићев институт, 2017. 7-26. Штампано.

Бојовић, Злата. Иво Анgрић и Дубровник. Приповетке и есеји, приредила Злата Бојовић, Андрићград: Андрићев институт, 2017. Штампано.

Дучић, Јован. „Иво Војновић“. Моји сайуйници, Београд-Требиње: ИП Рад, Октоих, Дучићеве вечери поезије, 2001. Штампано.

Ђорђевић, Бојан. „Наративност предела: Андрићеви медитерански записи“. Acqa alta Meguйерански йејзажи у моgерној срйској и ийалијанској књижевностичи, ур. С. Шеатовић Димитријевић, П. Лазаревић Ди Ђакомо, М. Рита Лето, 507-517, ИКУМ: Београд, 2013. Штампано.

Реста, Катерина. Геобилозофија Меgииеерана. превела Анђела Арсић Миливојевић. Београд: Геопоетика, 2017. Штампано. Стипчевић, Никша. „Андрићево читање извештаја млетачких амбасадора“. Свеске Заяужбине Иве Анgрића (1985): 111-169. Штампано.

Секви, Ерос. „Андрић, Италија и Италијани“. Иво Анgрић. Београд: Институт за књижевност и уметност, 1962. Штампано. Цвијић, Јован. Психиче особине Јужних Словена. Београд: СК3, 2006. Штампано.

Шеатовић, Светлана. „Брђанска туга и умереност приморја - Андрићев Јадран“. Иво Анgрић у нашем времену. Алек- 
сандра Вранеш (ур.). Андрићград-Вишеград: Андрићев институт, 2018. 43-64. Штампано.

Шеатовић Димитријевић, Светлана. „Његошева слика Италије и Латина“. Научни састианак славистиа у Вукове gане, МСЦ (2014): 471-481. Штампано.

\section{Svetlana Šeatović}

\section{THE LATIN WORLD IN ANDRIC'S SHORT STORIES AND DUCIC'S ESSAYS - THE SILENT WINNERS}

The origin of the image of the Latin people in folk literature is defined in this paper through stories of Ivo Andrić, an essay by Jovan Dučić and a travelogue of Miloš Crnjanski. The Adriatic belt and Dubrovnik as the toponym and synonym of the city is recognized as a place under the influence of Latin people and Venice. We have pointed to a modern anthropological awareness of the relationship between land and sea through the interpretation of Ivo Andrićs stories and essays. In addition to Ivo Andric's selected short stories “The Road of Alija Djerzelez", "Two Writings on the Bosnian Scribe Drazeslav" we also follow the ideas about the Latin world in Jovan Dučić's essay on Ivo Vojnović, as well as the travelogues of Milos Crnjanski. In its analyses, the paper relies on knowledge of geophilosophy (of K. Rest) and the anthropology of Jovan Cvijic. In concluding remarks, the paper focuses on the forms of Latinization that originated from Dubrovnik and the coastal zone of the Adriatic Sea as a form of "quiet" occupation of the Slovene population through forms of culture and religion. 